\section{Comparison of Two Citrus Bud-forcing Methods for Rapid Propagation of Scions on New Hybrid Citrumelo Rootstocks}

\author{
Kim D. Bowman \\ U.S. Department of Agriculture, Agricultural Research Service, U.S. \\ Horticultural Research Laboratory, 2120 Camden Road, Orlando, FL 32803 \\ Additional index words. budding, Citrus sinensis, Citrus reticulata, nursery, Thielaviopsis \\ basicola, Colletotrichum gloeosporioides
}

\begin{abstract}
Bending was compared to cutting off for effectiveness in forcing growth of sweet orange and mandarin scions budded on 'Carrizo' citrange, 'Swingle' citrumelo, and 17 new hybrid citrumelo rootstocks. For both scion types, more than twice as many plants from the bending treatment than the cut treatment had growing scion buds at 12 weeks. This advantage of the bending treatment was similar for most scion/rootstock combinations except with sweet orange scion on 'Carrizo', which produced outstanding bud growth from both forcing methods. Length of growing shoots at 12 weeks was $>14$ times longer from the bending than the cut treatment for both scions and with all rootstocks. Tree survival and yield of usable trees at 35 weeks old were also significantly better for the bending treatment than for the cut treatment. There was an overwhelming advantage to using the bending treatment instead of cutting off in forcing scion bud growth for propagating citrus trees on citrumelo rootstocks.
\end{abstract}

Several methods of forcing scion bud growth after budding are used for citrus, including bending, lopping, notching, cutting off (topping), and combinations of these four methods. In most comparisons of forcing methods, leaving some of the rootstock shoot attached to the plant (i.e., bending, lopping, or notching) during early stages of scion bud growth results in more scion elongation than cutting it off (Rouse, 1988; Williamson and Maust, 1993, 1996; Williamson et al., 1992). However, bending has also been associated with slower budbreak, or lower frequency of budbreak when compared with cutting off, especially when used with a citrumelo [Citrus $\times$ paradisi Macf. x Poncirus trifoliata(L.) Raf.] rootstock (Williamson and Maust, 1996). This can present serious problems in producing a specified number of field-ready grafted trees on a predetermined time schedule. The only previously published study that compared budbreak from bending vs. cutting treatments on 'Swingle' citrumelo rootstock (the most common type of citrus rootstock used in Florida) indicated that the low percentage and slower budbreak obtained following bending made it "unacceptable" for 'Swingle' citrumelo (Williamson and Maust, 1996). Commercial nurseries in Florida often use different methods (bending, lopping, or cutting off) depending on their experience with each particular

Received for publication 29 Sept. 1997. Accepted for publication 7 July 1998. Mention of a trademark, warranty, proprietary product, or vendor does not constitute a guarantee by the U.S. Dept. of Agriculture and does not imply its approval to the exclusion of other products or vendors that may also be suitable. The cost of publishing this paper was defrayed in part by the payment of page charges. Under postal regulations, this paper therefore must be hereby marked advertisement solely to indicate this fact. rootstock. When new hybrid rootstock selections are first being budded for use in replicated field testing, there is often no previous information available on budding on such rootstocks, the supply of rootstock seeds and liners may be very limited, and there is not time to conduct forcing experiments for each rootstock. The following experiment was conducted to determine the best overall forcing method to use in this situation. The objectives of this test were to compare the effects of bending vs. cutting off on scion budbreak, plant survival, shoot growth, and production of field-ready trees propagated on a typical group of new trifoliate hybrid rootstock selections. Some hybrids of this type may be expected to combine such qualities as apomictic reproduction, conferring high fruit quality and productivity on scions, and resistance to citrus tristeza virus, citrus nematode (Tylenchulus semipenetrans Cobb), citrus blight (no causative organism has been identified), and Phytophthora nicotianae Breda de Haan.

\section{Materials and Methods}

Seventeen new U.S. Dept. of Agriculture citrumelo hybrid rootstocks [16 Citrus $\times$ paradisi Macf. $x$ Poncirus trifoliata (L.) Raf. hybrids and one $C$. grandis (L.) Osbeck $\times P$. trifoliata hybrid] were selected because of source tree health in the field, fruitfulness, seediness, predominant nucellar embryony, and trueness-to-type from seed. Seeds of these selections and the common citrus rootstocks 'Carrizo' citrange [C. sinensis (L.) Osbeck X $P$. trifoliata $]$ and 'Swingle' citrumelo $(C$. $\times$ paradisi $\times$ P. trifoliata) were planted in a peat/perlite/vermiculite potting mix (Pro-Mix BX; Premier Horticulture, Inc., Red Hill, Pa.) at a rate of one seed per cell $\left(140 \mathrm{~cm}^{3}\right)$ in multicell trays (Multi-Pots; Can-Am Containers, Springhill, N.S., Canada). Individual seedlings were transplanted to $11-\mathrm{L}$ containers at 3 to 5 months of age (except 'Carrizo', which was transplanted at 7 months) and maintained on elevated benches in a greenhouse that had an average diurnal temperature cycle of $35^{\circ} \mathrm{C}$ maximum and $23{ }^{\circ} \mathrm{C}$ minimum at the beginning (August) and end (April) of the bud forcing experiment, and a diurnal cycle of 32 and $20{ }^{\circ} \mathrm{C}$ in the middle of the experiment (December). Sunlight was filtered through greenhouse fiberglass sheeting and no supplemental light was supplied. The photoperiod (sunrise to sunset) fluctuated from the beginning to the end of the experiment from $\approx 13 \mathrm{~h}$ $23 \mathrm{~min}$ in August, to $10 \mathrm{~h} 18 \mathrm{~min}$ in December, to $12 \mathrm{~h} 52 \mathrm{~min}$ in April. Maximum photosynthetic photon flux $(P P F)$ in the greenhouse was $800 \mu \mathrm{mol} \cdot \mathrm{s}^{-1} \cdot \mathrm{m}^{-2}$. Plants were watered as needed, alternating every other irrigation between non-amended well water and a watersoluble fertilizer mix (15N-16P-17K; Peters Fertilizer Products, W.R. Grace, Fogelsville, $\mathrm{Pa}$.) applied with a proportioner at a rate of 380 $\mathrm{mg} \cdot \mathrm{L}^{-1} \mathrm{~N}$. At the beginning of the experiment, 1.5 g Kocide 101 (Griffin Corp., Valdosta, Ga.) and $3.5 \mathrm{~g}$ Sequestrene 138 Fe (CibaGeigy Corp., Greensboro, N.C.) were applied to each 11-L container to provide copper and iron, respectively, to the growing plants.

Seedlings of each rootstock were budded on 16-17 Aug., $\approx 5$ to 6 months after planting (8 months for 'Carrizo'), half with 'Hamlin' sweet orange $(C$. sinensis) and half with 'Ninkat' mandarin (C. reticulata Blanco). Buds were inserted using an inverted-T cut at 7-13 $\mathrm{cm}$ above the soil. All seedlings were topped at $40 \mathrm{~cm}$ above the bud immediately after budding, except for one new hybrid citrumelo that was cut at $30 \mathrm{~cm}$. Three weeks after budding, the budding tape was removed and the shoot was either cut off $10 \mathrm{~cm}$ above the bud, or was bent, beginning $5 \mathrm{~cm}$ above the bud, down and back to the horizontal to form a $270^{\circ}$ loop. A total of 95 and 78 plants budded with 'Hamlin' and 'Ninkat', respectively, were subjected to the cut treatment, and 78 and 95 plants budded with 'Hamlin' and 'Ninkat', respectively, to the bending treatment. Plants were selected randomly for application of the cut or bent treatments within each scion/rootstock combination and these plants were grown side-byside on the greenhouse bench throughout. Periodically during the experiment, callus that had grown over inactive buds was removed. Eleven weeks after budding, plants that had been cut at $10 \mathrm{~cm}$ above the bud were recut at $5 \mathrm{~cm}$ above the bud, and plants that had been bent (but buds were not growing) were notched at $5 \mathrm{~cm}$ above the bud. Growing scion buds were pruned to single shoots for the first 12 weeks and trained vertically along stakes. About 25 weeks after budding, or once scions were taller than $50 \mathrm{~cm}$, all remaining loops from bent liners were removed. Bud growth was measured 12 weeks after budding and again at 35 weeks, just prior to field planting. Survival of grafted trees was scored after 31 weeks. Means of the four measured characteristics for the two treatments were compared 
for each scion by analysis of variance using Statistica ver. 5.0 (Statsoft Inc., Tulsa, Okla.). Different rootstocks with the same scion were considered as replicates of the treatments for statistical analysis.

\section{Results and Discussion}

Under the conditions used in this test, the bending treatment was superior overall for rapid budbreak, vigorous shoot growth, and bud and rootstock survival for producing healthy trees for field planting (Table 1). The bending treatment was superior in every respect to the cut treatment for both 'Hamlin' and 'Ninkat' scions on 14 of the 19 trifoliate hybrid rootstocks tested. Although the cut treatment was about equal to the bending treatment in one or two measured responses for one of the scions on the remaining five rootstocks, the bending treatment appeared to be better overall for all of the 19 rootstocks tested.

Trees large enough for transplanting to the field were obtained from 14 of the rootstocks budded with 'Hamlin'. Highly significant differences were noted between the bending and cut treatments for each of the four responses. Overall percentage of scion buds growing at 12 weeks was much greater for the bending than for the cut treatment ( $77 \%$ vs. $33 \%$ ), and bending induced more buds to grow on 16 of the 19 rootstocks. For the other rootstocks, like 'Carrizo,' the difference was insignificant. Average 'Hamlin' shoot length at 12 weeks was $>14$ times as great for the bending than for the cut treatment overall, and scion shoot length on all 19 rootstocks was much longer following bending.

Trees of 'Ninkat' on all 19 rootstocks reached sufficient size for transplanting to the field. Bending significantly increased the production of usable trees, and for many rootstocks the only usable trees were those that had been bent. Bending also induced much greater shoot growth, a higher percentage of scion buds growing at 12 weeks, and greater tree survival. 'Ninkat' on 'Carrizo' was the only combination for which $>50 \%$ of the plants from the cut treatment reached usable size in 35 weeks. Whether this was due to the stronger nursery behavior of 'Carrizo' than of citrumelos, better compatibility between 'Carrizo' and 'Ninkat', or the fact that the 'Carrizo' liners were 2 to 3 months older than the other rootstocks when they were budded could not be determined.

A previous study indicated that forcing by bending produced an unacceptably low percentage of budbreak for trees on 'Swingle'

Table 1. Comparison of bud growth following cutting and bending treatments with two scion cultivars and 17 new hybrid citrus rootstocks, 'Carrizo' citrange, and 'Swingle' citrumelo.

\begin{tabular}{|c|c|c|c|c|c|c|c|c|c|}
\hline \multirow[b]{2}{*}{ Scion } & \multirow[b]{2}{*}{ Rootstock } & \multicolumn{2}{|c|}{$\begin{array}{c}\text { Scion buds } \\
\text { growing at } \\
12 \text { weeks }(\%)\end{array}$} & \multicolumn{2}{|c|}{$\begin{array}{c}\text { Scion shoot } \\
\text { length }^{\mathrm{y}} \text { at } \\
12 \text { weeks }(\mathrm{cm})\end{array}$} & \multicolumn{2}{|c|}{$\begin{array}{c}\text { Bud and stock } \\
\text { survival at } \\
31 \text { weeks }(\%)\end{array}$} & \multicolumn{2}{|c|}{$\begin{array}{c}\text { Usable trees }^{2} \\
\text { at } 35 \text { weeks } \\
(\%)\end{array}$} \\
\hline & & $\overline{\text { Cut }}$ & $\overline{\text { Bent }}$ & Cut & $\overline{\text { Bent }}$ & Cut & Bent & $\overline{\text { Cut }}$ & Bent \\
\hline \multirow[t]{4}{*}{ Hamlin } & Carrizo & 100 & 100 & 3 & 46 & 100 & 100 & 20 & 100 \\
\hline & Swingle & 20 & 60 & 1 & 44 & 100 & 100 & 20 & 80 \\
\hline & 17 Hybrids & 28 & 76 & 1 & 25 & 72 & 100 & 4 & 56 \\
\hline & All $19^{x}$ & 33 & $77^{* * * *}$ & 2 & $28^{* * * *}$ & 75 & $100^{* * * *}$ & 5 & $60^{* * * *}$ \\
\hline \multirow[t]{4}{*}{ Ninkat } & Carrizo & 60 & 100 & 2 & 62 & 100 & 100 & 100 & 100 \\
\hline & Swingle & 20 & 60 & 2 & 48 & 100 & 100 & 0 & 60 \\
\hline & 17 Hybrids & 15 & 33 & 0 & 35 & 68 & 94 & 10 & 53 \\
\hline & All $19^{x}$ & 19 & $39^{*}$ & 2 & $41^{* * * *}$ & 72 & $95^{* *}$ & 15 & $56^{* * * *}$ \\
\hline
\end{tabular}

${ }^{2}$ Grafted trees at least $65 \mathrm{~cm}$ tall.

${ }^{y}$ Average shoot length for all shoots that were growing.

'Includes 17 hybrids, 'Carrizo', and 'Swingle'. Different rootstocks were considered as replicates for statistical analysis.

${ }^{*}, * *, * * *$ Bent significantly greater than cut by $\mathrm{F}$ test at $P \leq 0.05,0.01$, or 0.001 , respectively. Statistical comparisons were conducted only on data for all 19 rootstocks combined.

citrumelo, while cutting was much more effective (Williamson and Maust, 1996). This is an economically important issue as nearly 5 million citrus trees are propagated on 'Swingle' citrumelo each year in Florida, and the finished nursery trees have a typical value of $\$ 3$ to $\$ 4$ each. This study showed that bending, when properly applied, produced better budbreak than cutting in trees with sweet orange or mandarin scion on 'Swingle' and 17 other citrumelo rootstocks.

Previous comparisons of citrus bud forcing have focused on four rootstocks: sour orange (Rouse, 1988), 'Cleopatra' (Williamson and Maust, 1993, 1996), 'Carrizo' citrange (Williamson and Maust, 1996; Williamson et al., 1992), and 'Swingle' citrumelo (Williamson and Maust, 1993; 1996). However, Williamson and Maust (1996) found some significant and important differences between rootstocks in forcing behavior. This study expands the number of rootstocks that have been evaluated for forcing behavior from four to 21 . The new rootstocks evaluated have potential for being cold hardy, disease resistant, and productive for citrus in Florida. This study is also the first to compare bud forcing methods using a mandarin scion.

Two of the most important components of forcing response for propagation of trees for use in research or commercial production are 1) tree survival in the nursery and 2) percentage of finished field-ready trees after a given time interval. Our study is the first to quantify the effect of cutting vs. bending on these components of forcing response, and demonstrates the superiority of the bending treatment. Causes of individual bud or tree death during the experiment were not formally as- sessed. However, it appeared that Thielaviopsis basicola (Berk. \& Br.) Ferr. and Colletotrichum gloeosporioides (Penz.) Sacc. often contributed to tree and bud decline and death.

The bending method was clearly advantageous for propagation of new citrumelo hybrid rootstocks for field testing. Other rootstock cultivars or different conditions of pre- or post-budding growth might yield different relative responses to bending vs. cutting, and the effects of minor variations in technique were not assessed. The particular cutting treatment described here was used by the USDA Whitmore Foundation Farm from the 1980s until the time of this test. The cutting treatment is generally more convenient and sanitary to use because it eliminates the clutter of stems and leaves among the propagated trees. However, the benefits to plant growth of forcing by bending appear to far outweigh these inconveniences.

\section{Literature Cited}

Rouse, R.E. 1988. Bud-forcing method affects budbreak and scion growth of citrus grown in containers. J. Rio Grande Valley Hort. Soc. 41:69-73.

Williamson, J.G., W.S. Castle, and K.E. Koch. 1992. Growth and ${ }^{14} \mathrm{C}$-photosynthate allocation in citrus nursery trees subjected to one of three bud-forcing methods. J. Amer. Soc. Hort. Sci. 117:37-40.

Williamson, J.G. and B.E. Maust. 1993. Rootstock shoot contributions to scion growth of containerized citrus nursery trees. Proc. Florida State Hort. Soc. 106:52-54.

Williamson, J.G. and B.E. Maust. 1996. Forcing treatment and rootstock affect budbreak and growth of containerized Citrus nursery trees. HortTechnology 6:134-137. 